During the study, it was found that the size of the root crop is controlled by the genotype, but its formation is more dependent on external environmental factors. For selection according to the parameter «length of the root crop», the following samples were selected: 18 days (Russia) and White brekfast (Germany), according to the "width of the root crop» - Belaya (Czech Republic), Zhara (Netherlands)

Key words: radish, morphotype, gene pole, leaf blade, coefficient of variation.

UDC 551.5:631.5:635.656:631.521:631.8

DOI 10.31395/2415-8240-2020-97-1-268-278

\title{
INFLUENCE OF MICROBIAL PREPARATIONS ON THE FORMATION OF PLANT STRUCTURE INDICATORS AND GRAIN YIELD OF SOYBEAN
} AND BEAN VARIETIES

\author{
O. S. CHYNCHYK, $S c D$ in Agriculture \\ S. Y. OLIFIROVYCH \\ State Agrarian and Engineering University in Podilya \\ V. O. OLIFIROVYCH, $P h D$ in Agriculture
}

Bukovinian State Agricultural Research Station of the Institute of Agriculture of the Carpathian Region NAAS

I. I. HUMENIUK, $P h D$ in Philology

State Agrarian and Engineering University in Podilya

У статті визначено ефективність використання мікробних препаратів у технології вирощування сої та квасолі звичайної. Показано вплив біологічних препаратів на зміну елементів структури урожаю досліджуваних сортів сої та квасолі звичайної та встановлено рівень прибавки урожаю зерна від бактеризації насіння.

Клюові слова: соя, квасоля звичайна, мікробіологічні препарати, елементи структури врожаю, урожайність зерна.

Introduction. Grain yield of soybean and bean varieties is a complex indicator, and its implementation largely depends on individual productivity: the number of productive nodes, beans per node, the number of seeds in the bean, grain size, determinant type of growth and height of the bottom bean, etc. [1-3]. The yield level of soybeans, as well as of other crops, is determined by the quantitative parameters of the structural elements and their combination both with each other and with other plant traits [4].

Analysis of recent research and publications. The main elements of soybean productivity, which determine the level of its yield, are the number of plants per unit area, the number of beans per plant, seeds per bean and the mass of 1000 seeds $[5,6]$. As a rule, the most productive forms of soybeans either combine the average values of the main elements of productivity, or some of them have maximum values, and 
others - the average. The number of productive nodes can increase due to the height of plants (varieties with incomplete type of growth - indeterminate), but this feature is undesirable due to the shading of the lower tiers, while reducing the flow of solar insolation to the plant. In the future there is a struggle for assimilators between the vegetative mass of the plant and the generative, where the first indicator has the advantage. This feature is inherent in the old varieties and varieties that are grown under irrigation in conditions of sufficient heat supply [3]. The formation of elements of soybean productivity and the degree of their development largely depend on environmental conditions, biological characteristics of the variety and technological measures of its cultivation [7-11].

The indicator of grain productivity of bean plants (grain weight per plant) is one of the main elements of the yield structure, due to the interaction of many genes, the influence of soil-climatic and agronomic conditions [12]. Thus, it is known about the positive effect of fertilizer on increasing the structure of the bean yield [13-15]. Growth-regulating drugs have a significant effect on the formation of the elements of the bean yield [16]. Also, in the process of research, a significant influence of the factors under study on the variability of the yield of beans was proved, the proportions of factors in its variability were determined, the tightness of relationships between the seeding rate of seeds and performance indicators of beans of different morphobiotypes was determined [17].

Soybeans, as a high-protein crop, need a lot of nitrogen. Nitrogen is often a limiting nutrient for the growth and development of soybean plants [18]. In the Forest-Steppe of Ukraine, in connection with the introduction of soybeans, a mandatory element of the technology of growing this crop is pre-sowing inoculation of seeds with bacterial preparations, which makes it possible to abandon the use of mineral nitrogen fertilizers or significantly reduce their use. This agricultural measure is important because soybeans use a lot of nitrogen for the formation of 1 quintal of seeds and the corresponding amount of by-products - 7.2-10.1 kg, and seed inoculation, as shown by the results of many years of research, increases nitrogen fixation by $40-60 \%$, intensifies the yield increase by $18 \%$ and promotes additional protein accumulation by $225 \mathrm{~kg} /$ ha compared to the control [19]. Studies carried out at the Institute of Feed and Agriculture of Podillia NAAS showed that bacterial fertilizers used to inoculate seeds increased nitrogen fixation, provided plants with nitrogen, and some drugs and phosphorus, which means they increased the immunity of soybeans, resistance against various diseases, that is, manifested the general effect of three different groups of biological products, positively influenced the formation of the grain yield of this crop [20]. Seed inoculation increased the number of beans and the weight of seeds on soybean plants. Each soybean variety has its own optimal parameters of the performance elements. There is a compensation mechanism for the formation of productivity elements in soybean crops. At a lesser density of plants, more beans and seeds are formed on plants and a large mass of 1000 seeds, and this reduces the loss of yield from crop density [21]. Highly efficient strains of nodule bacteria increase yield and quality of beans [22]. 
Research methodology. Scientific research was performed by conducting field and laboratory experiments. The researches were conducted at the State Agrarian and Engineering University in Podilya and Bukovinian State Agricultural Research Station of the Institute of Agriculture of the Carpathian Region NAAS. The soil of the experimental field of the State Agrarian and Engineering University in Podilya - it is deep leached heavy-loam chernozem on forest-like loams. The experimental plot has the following agrochemical parameters (in the soil layer $0-30 \mathrm{~cm}$ ): humus content $-4.34 \% ; \mathrm{pH}-6.8$; easily hydrolyzed nitrogen $-124 \mathrm{mg} / \mathrm{kg}$ of soil; mobile phosphorus - $86 \mathrm{mg} / \mathrm{kg}$ of soil; exchangeable potassium - $167 \mathrm{mg} / \mathrm{kg}$ of soil. The soil of the experimental field of Bukovinian State Agricultural Research Station - it is meadow chernozem podzolic with heavy loam. The experimental plot has the following agrochemical parameters (in the soil layer $0-30 \mathrm{~cm}$ ): humus content - 3.91\%; pH 6.1; mobile phosphorus - $110 \mathrm{mg} / \mathrm{kg}$ of soil; exchangeable potassium - $195 \mathrm{mg} / \mathrm{kg}$ of soil. The research was conducted in accordance with generally accepted modern methods in crop production [23].

Research results. Harvest structure analysis is an important method for assessing the development of soybeans and common beans. Plant height, lodging and attachment height of the lower beans are some of the main attributes of soybeans that determine its suitability for full mechanized cultivation from sowing to harvesting. In our studies, the height of the plants changed depending on the variety, the year of cultivation and agricultural techniques, studied. But varietal characteristics were decisive. So, in the variant without the use of biological products, the height of soybean plants of the Estafeta variety was $82.1 \mathrm{~cm}$, the Constellation variety $76.5 \mathrm{~cm}$, the Danae variety $-109.8 \mathrm{~cm}$ (table 1$)$.

Table 1. Structure of soybean yield depending on cultivar, seed inoculation and nutrition (State Agrarian and Engineering University in Podilya, 2017-2019)

\begin{tabular}{|c|c|c|c|c|c|c|c|}
\hline \multirow{2}{*}{$\stackrel{\overrightarrow{0}}{\stackrel{0}{\pi}}$} & \multirow{2}{*}{$\begin{array}{l}\text { Plant } \\
\text { height, } \\
\mathrm{cm}\end{array}$} & \multirow{2}{*}{$\begin{array}{l}\text { Bottom bean } \\
\text { attachment } \\
\text { height, cm }\end{array}$} & \multicolumn{3}{|c|}{ Quantity, pieces. } & \multirow{2}{*}{$\begin{array}{c}\text { Grain } \\
\text { weight per } \\
\text { plant, } g\end{array}$} & \multirow{2}{*}{$\begin{array}{l}\text { Weight } \\
\text { of } 1000 \\
\text { grains, } g\end{array}$} \\
\hline & & & $\begin{array}{c}\text { grains in } \\
\text { beans }\end{array}$ & $\begin{array}{l}\text { beans per } \\
\text { plant }\end{array}$ & $\begin{array}{c}\text { grains per } \\
\text { plant }\end{array}$ & & \\
\hline \multicolumn{8}{|c|}{ Without inoculation } \\
\hline Estafeta & 82.1 & 9.7 & 1.86 & 26.1 & 48.5 & 7.8 & 160.8 \\
\hline Suzirria & 76.5 & 9.1 & 1.91 & 33.1 & 63.2 & 10.2 & 161.4 \\
\hline Danaia & 109.8 & 17.8 & 2.01 & 30.9 & 62.1 & 9.8 & 157.8 \\
\hline \multicolumn{8}{|c|}{ Rhizobophyte } \\
\hline Estafeta & 85.7 & 10.3 & 1.85 & 26.7 & 49.1 & 7.9 & 160.9 \\
\hline Suzirria & 82.8 & 9.5 & 1.89 & 34.4 & 65.0 & 10.5 & 161.4 \\
\hline Danaia & 118.4 & 19.9 & 1.98 & 32.1 & 63.6 & 10.1 & 158.2 \\
\hline \multicolumn{8}{|c|}{ Rhizobophyte + Phosphoenterine + Biopolycid } \\
\hline Estafeta & 84.4 & 10.2 & 1.88 & 26.9 & 50.6 & 8.2 & 162.1 \\
\hline Suzirria & 82.1 & 9.8 & 1.92 & 35.7 & 68.5 & 11.2 & 163.5 \\
\hline Danaia & 120.0 & 19.7 & 2.0 & 32.5 & 65.0 & 10.3 & 158.5 \\
\hline
\end{tabular}


No less important indicator than the height of soybean plants is the attachment height of the bottom bean. After all, the location of the bottom bean at least $10-12 \mathrm{~cm}$ above the soil surface is considered optimal for direct harvesting with a combine. In our studies, in the non-biological version, the height of attachment of the bottom bean on soybean plants of the Estafeta variety was $9.7 \mathrm{~cm}$, that of the Suzirria variety was $9.1 \mathrm{~cm}$, and that of the Danaia variety was $17.8 \mathrm{~cm}$. On average, for 2017-2019, the maximum height of the studied plants was $120 \mathrm{~cm}$ in the Danaia soybean variety when treating seeds with Rhizobophyte, Phosphoenterine and Biopolycid. The same variety in the variant with Rhizobophyte seed inoculation had a high attachment height of the bottom bean $-19.9 \mathrm{~cm}$.

One of the main features of the structure of the soybean crop is the number of beans per plant. In our studies, the range of this indicator in the studied soybean varieties was noted in the range from 26.1 to 35.7 pcs./plant. Closely related to the indicators of the number of beans is the number of grains per plant of soybeans, which in the studied varieties varied from 48.5 to $68.5 \mathrm{pcs} . / \mathrm{plant}$.

The mass of grains from the plant is one of the main features that determines the final productivity of soybeans. In the control (without the use of biological products) the weight of grains from one soybean plant of the Suzirria variety was $10.2 \mathrm{~g}$, the Danaia variety - $9.8 \mathrm{~g}$, and the Estafeta variety - only $7.8 \mathrm{~g}$. Inoculation of Rhizobophyte seeds and complex use of biological products (Rhizobophyte + Phosphoenterine + Biopolycid) increased the individual productivity of soybean plants. In particular, in the variant with seed treatment of Rhizobophyte, Phosphoenterine and Biopolycid, the weight of grains from one soybean plant of the Estafeta variety increased to $8.2 \mathrm{~g}$, of the Danaia variety to $10.3 \mathrm{~g}$, and of the Suzirria variety to $11.2 \mathrm{~g}$.

In our studies, the use of different types of fertilizers and genetic characteristics of varieties significantly affected the structure of the bean yield. The smallest number of beans per plant of the Bukovynka bean variety was observed in areas without seed inoculation - $9.6 \mathrm{pcs}$. The Nata bean variety was characterized by a large number of beans (10.0 pcs.) and grains (41.9 pcs.) per plant. Seed inoculation increased the number of beans and seed weight on plants of the studied varieties. Thus, with the use of Rhizoactive on crops of Bukovynka beans 10.1 beans and 42.3 pieces of grains per plant were formed, Nata variety -10.8 beans and 46.3 pieces of grains on one plant. In addition to the number of beans and grains per plant, the weight of thousands of grains is of great importance in individual productivity. The Nata bean variety was characterized by a greater mass of 1000 grains. In the control (without inoculation) the weight of 1000 grains of this variety was $219.6 \mathrm{~g}$, and the Bukovynka bean variety $-217.0 \mathrm{~g}$ (table 2$)$.

The use of Rhizoactive increased the weight of 1000 grains in the Bukovynka bean variety from 217.0 to $219.9 \mathrm{~g}$, in the Nata bean variety - from 219.6 to $224.6 \mathrm{~g}$.

Studies have shown that biological products based on nitrogen-fixing and phosphate-mobilizing bacteria can significantly increase soybean productivity. 
Table 2. The structure of the bean harvest depending on the variety, seed inoculation and nutrition (Bukovinian State Agricultural Research

Station, 2017-2019)

\begin{tabular}{|c|c|c|c|c|c|c|c|}
\hline \multirow[b]{2}{*}{$\begin{array}{l}\frac{2}{0} \\
\frac{0}{\pi} \\
>\end{array}$} & \multirow[b]{2}{*}{$\begin{array}{l}\text { Plant } \\
\text { height, } \\
\mathrm{cm}\end{array}$} & \multirow[b]{2}{*}{$\begin{array}{l}\text { Bottom bean } \\
\text { attachment } \\
\text { height, cm }\end{array}$} & \multicolumn{3}{|c|}{ Quantity, pieces } & \multirow[b]{2}{*}{$\begin{array}{c}\text { Grain } \\
\text { weight per } \\
\text { plant, } \mathrm{g}\end{array}$} & \multirow[b]{2}{*}{$\begin{array}{l}\text { Weight } \\
\text { of } 1000 \\
\text { grains, } g\end{array}$} \\
\hline & & & $\begin{array}{l}\text { grains } \\
\text { in } \\
\text { beans }\end{array}$ & $\begin{array}{c}\text { beans per } \\
\text { plant }\end{array}$ & $\begin{array}{c}\text { grains per } \\
\text { plant }\end{array}$ & & \\
\hline \multicolumn{8}{|c|}{ Without inoculation } \\
\hline Bukovynka & 48.6 & 9.3 & 4.2 & 9.6 & 40.1 & 8.7 & 217.0 \\
\hline Nata & 55.5 & 11.8 & 4.2 & 10.0 & 41.9 & 9.2 & 219.6 \\
\hline \multicolumn{8}{|c|}{ Rhizoactive } \\
\hline Bukovynka & 50.7 & 9.7 & 4.2 & 10.1 & 42.3 & 9.3 & 219.9 \\
\hline Nata & 56.1 & 12.0 & 4.3 & 10.8 & 46.3 & 10.4 & 224.6 \\
\hline
\end{tabular}

Thus, on average for 2017-2019, the yield of soybean grain under control (the Estafeta variety, seed treatment with water) was $2.23 \mathrm{t} / \mathrm{ha}$. However, this was not the best indicator and among the studied varieties in the variant without the use of biological products, the maximum yield was $2.66 \mathrm{t} / \mathrm{ha}$ in the soybean of the Suzirria variety. Bacterization of seeds with Rhizobophyte increased the grain yield in the Estafeta variety by 0.05 t/ha compared to the control, but the best level of grain yield in this variant was observed in the Suzirria soybean variety and amounted to $2.81 \mathrm{t} / \mathrm{ha}$, which was $0.15 \mathrm{t} / \mathrm{ha}$ more than in the control. The highest yields in the experiment were provided by treatment of soybean seeds with Rhizobophyte, Phosphoenterin and Biopolycid. Thus, the yield of the Estafeta soybean variety was $2.35 \mathrm{t} / \mathrm{ha}$ and was $0.12 \mathrm{t} / \mathrm{ha}$ higher than the control variant (table 3 ).

Table 3. Yield of soybean varieties in the experimental field of the State Agrarian and Engineering University in Podilya depending on the use of biological products (average for 2017-2019)

\begin{tabular}{|c|c|c|}
\hline Biologics & Variety & Grain yield, t/ha \\
\hline \multirow{2}{*}{$\begin{array}{c}\text { Seed treatment with } \\
\text { water (k) }\end{array}$} & Estafeta & 2,23 \\
\cline { 2 - 3 } & Suzirria & 2,66 \\
\cline { 2 - 3 } & Danaia & 2,61 \\
\hline \multirow{2}{*}{ Rhizobophyte } & Estafeta & 2,28 \\
\cline { 2 - 3 } & Suzirria & 2,81 \\
\cline { 2 - 3 } & Danaia & 2,78 \\
\hline Rhizobophyte + & Estafeta & 2,35 \\
\cline { 2 - 3 } Phosphoenterine + & Suzirria & 2,97 \\
\cline { 2 - 3 } Biopolycid & Danaia & 2,98 \\
\hline$L S D_{05}$ & - & 0,12 \\
\hline
\end{tabular}

The maximum yield in this seed treatment was in the Suziria and Danaya soybean varieties and was 2.97 and $2.98 \mathrm{t} / \mathrm{ha}$, respectively. 
It was found that the average yield of beans under control in 2017-2019 (the Bukovynka variety without bacterial fertilizers) was $2.22 \mathrm{t} / \mathrm{ha}$ (table 4).

Table 4. Productivity of common beans varieties on the experimental field of

Bukovinian State Agricultural Research Station depending on the use of

Rhizoactive (on average for 2017-2019)

\begin{tabular}{|c|c|c|}
\hline Biologics & Variety & Grain yield, $\mathrm{t} / \mathrm{ha}$ \\
\hline \multirow{2}{*}{ Seed treatment with water (k.) } & Bukovynka & 2,22 \\
\cline { 2 - 3 } & Nata & 2,38 \\
\hline \multirow{2}{*}{ Rhizoactive } & Bukovynka & 2,31 \\
\cline { 2 - 3 } & Nata & 2,58 \\
\hline$L S D_{05}$ & - & 0,09 \\
\hline
\end{tabular}

Among the studied varieties in the variant without the use of fertilizers, the higher grain yield was in the Nata bean variety -2.38 t/ha.

The productivity of beans was significantly affected by inoculation of seeds with Rhizobophyte: the Bukovynka variety grain yield was increased by $0.09 \mathrm{t} / \mathrm{ha}$ or $4 \%$, Nata variety - by 0.17 t/ha or $7 \%$.

Conclusions. On average for 2017-2019, the maximum height of the studied plants was in Danaia soybeans when treating seeds with Rhizobophyte, Phosphoenterin and Biopolycid and it was $120 \mathrm{~cm}$. In the same variant of using biological products, the Suzirria soybean variety produced the largest number of beans, grains and grain weight per plant. The Suzirria soybeans provided the best yield structure. In particular, in the variant with seed treatment with Rhizobophyte, Phosphoenterin and Biopolycid, the weight of grains from one soybean plant of the the Suzirria variety was $11.2 \mathrm{~g}$, the Danaia variety - $10.3 \mathrm{~g}$, and the Estafeta variety - only $8.2 \mathrm{~g}$. Bacterization of sowing material with biological products contributed to the increase of grain productivity of soybean plants by $5-12 \%$. The highest grain gain from the use of microbiological preparations was provided by the Suzirria and the Danaia varieties.

In terms of research, the Nata bean variety was more productive, forming 10.2$10.4 \mathrm{~g}$ of grain per plant, which was $0.2-1.2 \mathrm{~g}$ more than the Bukovynka bean variety. The highest grain gain from the use of Rhizoactive was provided by the Nata variety.

\section{Література}

1. Стаканов Ф. С. Фасоль. Кишинев: Штииница, 1986. 195 с.

2. Акуленко В. В. Ріст рослин квасолі звичайної залежно від технології вирощування в північній частині Лісостепу. Вісник Центру наукового забезпечення АПВ Харківської області. 2014. Вип. 16. С. 5-11.

3. Іванюк С. Потенціал продуктивності соєвого поля. Агробізнес сьогодні. 2015. №21 (316). С. 50-55. 
4. Браценюк В. Ю. Вплив способів сівби та передзбиральної десикації на продуктивність сортів сої різних груп стиглості. Збірник наукових праць ННЦ “Інститут землеробства НААН”. 2017. Вип. 1. С. 83-92.

5. Бабич А. О. Сучасне виробництво і використання сої. К.: Урожай. $1993.429 \mathrm{c}$.

6. Агробиологические особенности возделывания сои в Украине. Ф. Ф. Адамень, В. А. Вергунов, П. Н. Лазер, И. Н. Вергунова. К.: Аграрна наука. 2006. $456 \mathrm{c}$.

7. Трухачев В. И., Клюшин П. В. Соя на Северном Кавказе: монография. Ставрополь: АГРУС, 2007. 532 с.

8. Lavrynenko Y. O., Kuzmych V. I., Klubuk V. V. Regression and correlation analysis of soybean productivity elements. Таврійський науковий вісник. 2015. № 92. C. 60-64.

9. Молдован В.Г., Молдован Ж.А., Собчук С.І. Формування врожаю сої залежно від технологічних елементів вирощування в умовах Правобережного Лісостепу України. Вісник ЖНАЕУ. 2015. № 2(50), т. 1. C. 279-285.

10. Чинчик О. С. Вплив способів удобрення на формування структури та врожайності сої (Glycine max (L.) Merr.) в умовах Лісостепу західного. Наук. пр. Інституту біоенергетичних культур і иукрових буряків. 2016. Вип. 24. C. $35-41$.

11. Шепілова Т.П., Петренко Д. І. Вплив способу сівби і норми висіву насіння на ріст і розвиток рослин сої. Вісник уманського національного університету садівництва. 2017. № 1. С. 74-77.

12. Наумкина Т. С., Суворова Г. Н., Васильчиков А. Г. Создание высокоэффективных растительно-микробных систем фасоли. Зернобобовые и крупяные культуры. 2012. № 2. С. 21-26.

13. Dhatonde B.N., Nalamwar R.V. Effect of nitrogen and irrigation levels on yield and water use of French bean (Phaseolus vulgaris). Ind. J. Agron. 1996. № 41 (2). C. $265-268$.

14. Abebe G. Effect of NP fertilizer and moisture conservation on the yield and yield components of haricot bean (Phaseolus vulgaris L.) in the semi-arid zones of the Central Rift Valley in Ethiopia. Adv. Environ. Biol. 2009. №3 (3). C. 302-307.

15. Turuko M., Mohammed. A. Effect of different phosphorus fertilizer rates on growth, dry matter yield and yield components of common bean (Phaseolus vulgaris L.). World J. Agri. Res. 2014. № 2 (3). C. 88-92.

16. Шляхтуров Д. С. Вплив регуляторів росту на урожайність квасолі. Землеробство. Міжсвідом. тем. наук. зб. 2014. Вип. 1-2. С. 84-87.

17. Рожков А. О., Труш О. К. Урожайність квасолі залежно від норми висіву насіння в східному Лісостепу України. Збірник наукових праџь Уманського національного університету садівництва. 2019. Вип. 94. Ч. 1. С. $165-174$. 
18. Imsande J. Rapid Dinitrogen Fixation During Soybean Pod Fill Enhances Net Photosynthetic Output and Seed Yield: A New Perspective. Agronomy Journal. 1989. Vol. 81. №. 4. P. 549-556.

19. Петриченко В. Ф., Лихочвор В. В., Іванюк С. В. та ін. Соя: монографія. Вінниця: «Діло», 2016. 400 с.

20. Ефективність біологічних препаратів на посівах сої. Задорожний В. С., Карасевич В. В., Свитко С. М. та ін. Корми і кормовиробництво. 2019. Вип. 87. С. 70-78.

21. Нетіс В. І. Формування елементів продуктивності сої за різни заходів вирощування. Таврійський науковий вісник. 2018. Вип. 99. С. 100-107.

22. Чундерова А. И. Влияние высокоефективных штаммов клубеньковых бактерий на урожай и содержание протеина в зерне фасоли. Селекция, семеноводство и приемы возделывания фасоли. Ред. кол.: Ф. К. Чапурин (главн. ред.). Орел: Труд, 1975. С. 192-195.

23. Єщенко В. О. та ін. Основи наукових досліджень в агрономії. Вінниця, 2014. 332 с.

\section{References}

1. Stakanov, F. S. (1986). Beans. Chisinau: Shtiinitsa, 1986. 195 p.

2. Akylenko, V. V. (2014). The growth of common bean plants depending on the cultivation technology in the northern part of the forest-steppe. Bulletin of the Center for Scientific Support of the APP of the Kharkiv Region, iss. 16, pp. 5-11.

3. Ivaniuk, S. (2015). Soybean field productivity potential. Agribusiness today, no. 21 (316), pp. 50-55.

4. Bratseniuk, V. Yu. (2017). Influence of sowing and pre-harvest desiccation methods on productivity of soybean varieties of different maturity groups. Bulletin of scientific works of NSC "Institute of Agriculture NAAS", iss. 1, pp. 83-92.

5. Babych, A. O. (1993). Modern production and use of soybeans. K.: Urozhai, $429 \mathrm{p}$.

6. Adamen, F. F., Verhunov, V. A., Lazer, P. N., Verhuniva, I. N. (2006). Agrobiological features of soybean cultivation in Ukraine. K.: Agrarna nauka, $456 \mathrm{p}$.

7. Truhachev, V. I., Kliushyn, P. V. (2007). Soybeans in the North Caucasus: monograph. Stavropol: AGRUS, 532 p.

8. Lavrynenko, Y. O., Kuzmych, V. I., Klubuk, V. V. (2015). Regression and correlation analysis of soybean productivity elements. Taurian Scientific Bulletin, no. 92 , pp. $60-64$.

9. Moldovan, V.H., Moldovan, Zh.A., Sobchuk, S.I. (2015). Formation of soybean harvest depending on technological elements of cultivation in the conditions of the Right-bank Forest-steppe of Ukraine. Bulletin of ZhNAEU, no. 2 (50), pp. 279285.

10. Chynchyk, O. S. (2016). Influence of fertilizer methods on the formation of structure and yield of soybean (Glycine max (L.) Merr.) in the conditions of the western Forest-Steppe. Scientific works of the Institute of Bioenergy Crops and Sugar Beets: bulletin of scientific works, issue 24, pp. 35-41. 
11. Shepilova, T.P., Petrenko, D. I. (2017). Influence of sowing method and seeding rate on growth and development of soybean plants. Bulletin of Uman National University of Horticulture, no.1, pp. 74-77.

12. Naumkina, T. S., Suvorova, G. N., Vasilchikov, A. G. (2012). Creation of highly efficient plant-microbial systems of beans. Legumes and cereals, no. 2, pp. 21-26.

13. Dhatonde, B.N., Nalamwar, R.V. (1996). Effect of nitrogen and irrigation levels on yield and water use of French bean (Phaseolus vulgaris). Ind. J. Agron, no. 41 (2), pp. 265-268.

14. Abebe, G. (2009). Effect of NP fertilizer and moisture conservation on the yield and yield components of haricot bean (Phaseolus vulgaris L.) in the semiarid zones of the Central Rift Valley in Ethiopia. Adv. Environ. Biol., no. 3 (3), pp. 302-307.

15. Turuko, M., Mohammed, A. (2014). Effect of different phosphorus fertilizer rates on growth, dry matter yield and yield components of common bean (Phaseolus vulgaris L.). World J. Agri. Res., no. 2 (3), pp. 88-92.

16. Shliahturov, D. S. (2014). Influence of growth regulators on bean yield. Agriculture. Interdepartmental thematic scientific bulletin, iss. 1-2, pp. 84-87.

17. Rozhkov, A. O., Trush, O. K. (2019). Bean yield depending on the seeding rate in the eastern Forest-steppe of Ukraine. Bulletin of scientific works of Uman National University of Horticulture, issue 94, pp. 165-174.

18. Imsande, J. Rapid Dinitrogen Fixation During Soybean Pod Fill Enhances Net Photosynthetic Output and Seed Yield: A New Perspective. Agronomy Journal, vol. 81, no. 4, pp. 549-556.

19. Petrychenko, V. F., Lyhochvor, V. V., Ivaniuk, S. V. et al. (2016). Soybean: a monograph. Vinnytsia: «Dilo», $400 \mathrm{p}$.

20. Zadorozhnyi, V. S., Karasevych, V. V., Cvytko, S. M. (2019). The effectiveness of biological drugs on soybean crops. Feed and feed production, issue 87, pp. 70-78.

21. Netis, V. I. (2018). Formation of elements of soybean productivity under different cultivation measures. Taurian Scientific Bulletin, issue 99, pp. 100-107.

22. Chunderova, A. I. (1975). Influence of highly effective strains of nodule bacteria on the yield and protein content in beans. Selection, seed production and methods of cultivation of beans. Orel: Trud, pp. 192-195.

23. Yeshchenko V. O. et al. (2014). Fundamentals of scientific research in agronomy. Vinnytsia, $332 \mathrm{p}$.

\section{Аннотация}

Чинчик А.С., Олифирович С.И., Олифирович В.А., Гуменюк И.И. Влияние микробных препаратов на формирование показателей структуры растений и урожайность зерна сортов сои и фасоли обыкновенной

Научные исследования выполнено путем проведения полевых $u$ лабораторных опытов. Исследования проводились в Подольском государственном аграрно-техническом университете и Буковинской 
государственной сельскохозяйственной опьтной станции Института сельского хозяйства Карпатского региона НААН.

В наших исследованиях отмечено размах количества бобов в исследуемых сортах сои в пределах от 26,1 до 35,7 шт/на растение. Тесно связано с показателями количества бобов количество зерен с растения сои, которое на исследуемых сортах изменялась в пределах от 48,5 до 68,5 шт/на растение. На контроле (без использования биопрепаратов) масса зерен с одного растения сои сорта Созвездие составляла 10,2 2, сорта Даная - 9,8 2, а сорта Эстафета - только 7,8 г. Инокуляция семян Ризобофитом и комплексное использование биопрепаратов (Ризобофит + Фосфоентерин + Биопалицид) повышали индивидуальную продуктивность растений сои. В частности, на варианте с обработкой семян Ризобофитом, Фосфоентерином $u$ Биополицидом масса зерен с одного растения сои сорта Эстафета выросла до 8,2 2, сорта Даная - до 10,3 2, а сорта Созвездие - до 11,2 2. Cамыле высокие показатели урожайности при исследовании обеспечивала обработка семян сои Ризобофитом, Фосфоентерином и Биополицидом. Так, урожайность сои сорта Эстафета составила 2,35 m/2а и была на 0,12 m/2а больше, по сравнению с вариантом контроля. Максимальная урожайность при указанной обработке семян была в сое сортов Созвездие и Даная и составила соответственно 2,97 и 2,98 m/2а.

В наших исследованиях применение различных видов удобрений $и$ генетические особенности сортов существенно влияли на структуру урожая фасоли. Наименьшее количество бобов на одном растении фасоли сорта Буковинка отмечено на участках без инокуляции семян - 9,6 ит. Сорт фасоли Ната характеризовался большим количеством бобов (10,0 шт.) и зерен (41,9 шт.) на одном растении. Инокулячия семян увеличивала количество бобов и массу семян на растениях исследуемых сортов. Так, при использовании Ризоактива на посевах фасоли сорта Буковинка формировалось 10,1 бобов и 42,3 шт. зерен на одном растении, сорта Ната — 10,8 бобов и 46,3 шт. зерен на одном растении. Среди изучаемых сортов на варианте без применения удобрений высшая урожайность зерна была у сорта фасоли Ната - 2,38 m/2а. B значительной степени на производительность фасоли влияла инокуляция семян Ризобофитом: урожайность зерна сорта Буковинка выросла на 0,09 m/га или 4\%, сорта Ната - на $0,17 \mathrm{~m} / 2$ али $7 \%$.

Ключевые слова: соя, фасоль обыкновенная, микробиологчческие препараты, элементы структуры урожая, урожайность зерна.

\section{Annotation}

\section{Chynchyk O. S., Olifirovych S. Y., Olifirovych V. O., Humeniuk I. I.} Influence of microbial preparations on the formation of plant structure indicators and grain yield of soybean and bean varieties

The mass of grains from the plant is one of the main features that determines the final productivity of soybeans. In the control (without the use of biological products), the weight of grains from one soybean plant of the Suzirria variety was $10.2 \mathrm{~g}$, of the Danaia variety - $9.8 \mathrm{~g}$, and of the Estafeta variety - only $7.8 \mathrm{~g}$. Seed inoculation with Rhizobophyte and complex use of biological products (Rhizobophyte + Phosphoenterin + Biopolycid) increased the individual productivity of soybean plants. In particular, in the variant with seed treatment with Rhizobophyte, 
Phosphoenterin and Biopolycid, the weight of grains from one soybean plant of the Estafeta variety increased to $8.2 \mathrm{~g}$, of the Danaia variety to $10.3 \mathrm{~g}$, and of the Suzirria variety to $11.2 \mathrm{~g}$.

The lowest number of beans per plant of Bukovynka beans was observed in areas without seed inoculation - 9.6 pcs. Nata beans were characterized by a larger number of beans (10.0 pieces) and grains (41.9 pieces) per plant. Seed inoculation increased the number of beans and seed weight on plants of the studied varieties. Thus, with the use of Rhizoactive on crops of Bukovynka beans, 10.1 beans and 42.3 grain pieces per plant were formed, Nata variety - 10.8 beans and 46.3 grain pieces on one plant. Among the studied varieties in the variant without the use of fertilizers, the higher grain yield was in the Nata bean variety $-2.38 \mathrm{t} / \mathrm{ha}$. The productivity of beans was significantly affected by inoculation of seeds with Rhizobophyte: grain yield of Bukovynka variety increased by 0.09 t/ha or $4 \%$, Nata variety - by $0.17 \mathrm{t} / \mathrm{ha}$ or $7 \%$.

Conclusions. Suzirria soybeans provided the best yield structure. In particular, in the variant with seed treatment with Rhizobophyte, Phosphoenterin and Biopolycid, the weight of grains from one soybean plant of the Suzirria variety was $11.2 \mathrm{~g}$, Danaia variety - $10.3 \mathrm{~g}$, and Estafeta variety - only $8.2 \mathrm{~g}$. Bacterization of seed by biological products contributed to the increase in grain productivity of soybean plants by 3-17\%.

Under the conditions of the research, the Nata bean variety was more productive, forming 10.2-10.4 g of grain per plant, which was $0.2-1.2 \mathrm{~g}$ more than the Bukovynka bean variety.

Key words: soybeans, common beans, microbiological preparations, elements of crop structure, grain yield. 